Article

\title{
The Words Change Everything: Haunting, Contagion and The Stranger in Tony Burgess's Pontypool
}

Evelyn Deshane ${ }^{1, *}$ and R. Travis Morton ${ }^{1}$

How to cite: Deshane, E. and Morton, R. T. 'The Words Change Everything: Haunting, Contagion and The Stranger in Tony Burgess's Pontypool.' London Journal of Canadian Studies, 2018, 33(1), pp. 58-76. DOI: https://doi.org/10.14324/111.444.ljcs.2018 v3 3.005 .

Published: 14 November 2018

\section{Peer Review:}

This article has been peer reviewed through the journal's standard double-blind peer-review, where both the reviewers and authors are anonymized during review.

\section{Copyright:}

(C) 2018, The Author(s). This is an Open Access article distributed under the terms of the Creative Commons Attribution License (CC-BY) 4.0 https://creativecommons.org/licenses/by/4.0/, which permits unrestricted use, distribution and reproduction in any medium, provided the original author and source are credited $\bullet$ DOI: https://doi.org/10.14324/111.444.ljcs.2018v33.005.

\section{Open Access:}

London Journal of Canadian Studies is a peer-reviewed open access journal.

\footnotetext{
*Correspondence: evelyndeshane@gmail.com and rtravismorton@gmail.com

${ }^{1}$ University of Waterloo, Canada
} 


\title{
The Words Change Everything: Haunting, Contagion and The Stranger in Tony Burgess's Pontypool
}

\author{
Evelyn Deshane and R. Travis Morton
}

\begin{abstract}
In 2018, O Canada's lyrics were made gender neutral. This change comes at a time when certain key public figures refuse to use gender neutral language. The linguistic tension and ideological divide within Canada creates a haunted feeling around certain minority groups, leaving everyone feeling out of place. This article examines how viral ideas and word choices spread through media technologies via the 'word virus'. We use the figure of the zombie to show how the word virus becomes bad ideology, one that spreads and takes over certain spaces and enacts the presence of the insider/outsider. To reflect on 'word viruses' gone awry, we borrow and build on scholarship from the emerging field of hauntology made popular by Jacques Derrida and Avery Gordon. Ultimately, we present Tony Burgess's horror novel Pontypool Changes Everything turned Canadian horror film Pontypool as a speculative case study, since Burgess's texts suggest that what is more infectious than the zombie-outsider is the insider's own language, which identifies and labels the outsider. By positing a possible cure for the word virus within Pontypool, the film adaptation suggests that the ways in which we cease becoming infected with bad ideas is not to stop speaking or isolate ourselves through quarantine, but deliberately seek out the stranger in order to challenge and change the meaning of words.
\end{abstract}

Keywords: hauntology, gender neutral language, transgender, communities, Canadian horror, film adaptation 


\section{Introduction}

In 2018, O Canada's lyrics were made gender neutral in order to foster and facilitate a more inclusive national image, yet the changes were not entirely well-received by those in government or in the larger public sphere. ${ }^{1}$ Similarly, when Bill C-16 was passed in order to prevent discrimination against gender identity on the Canadian Charter of Rights and Freedom, numerous politicians and Canadian figures voiced their dissent quite publicly. ${ }^{2}$ The linguistic tension and ideological divide within Canada creates a haunted feeling around certain identity groups, especially that of the transgender or gender nonconforming person who is the assumed subject of much of these policy changes, but these tensions also fracture the national public sphere and leaves everyone inside Canada's borders feeling infected, afflicted, haunted, or merely 'out of place'. ${ }^{3}$ Our paper examines the connection between haunting and contagion through the spread of 'word viruses' in certain forms of media and how these viruses attach themselves to specific identity groups, creating a divide between communities. We build on scholarship from the emerging field of 'hauntology'4 made popular by Jacques Derrida, Avery Gordon and Ann Cvetkovich, and we situate these ideas through an examination of the Canadian horror film Pontypool ${ }^{5}$ and the novel on which it is based called Pontypool Changes Everything. ${ }^{6}$ Tony Burgess's novel, and especially the Bruce McDonald film adaptation which Burgess also wrote, changes the locus of infection so common in zombie films from the bodily to the ideological, from the bite of the stranger to the use of a familiar word. In doing so, Pontypool suggests that what is more infectious than the zombieoutsider is the insider's language, and how we as a community have labeled the outsider as such. Moreover, by positing a possible cure for the 'word virus' contagion within Pontypool, the film adaptation suggests that the ways in which to avoid becoming infected with bad ideas is not to isolate through quarantine or prohibit speech, but instead deliberately seek out the stranger and change the meaning of the word itself. Rather than prohibiting any kind of speech - be it a gender-neutral pronoun or something far more odious - we should attempt a facilitated discussion between groups, identities and those deemed 'out of place'. ${ }^{7}$

\section{The History of Queer Hauntings}

Jacques Derrida's Specters of Marx has been the basis for much of the work being done in the field of 'hauntology'. ${ }^{8}$ It is his chapter on 'the 
conjuring trick' that presents the issue of speech prohibition most succinctly. Derrida writes that

[a]n articulation assures the movement of this relentless indictment. It gives some play. It plays between the spirit (Geist) and the specter (Gespenst), between the spirit on the one hand, the ghost or the revenant on the other. This articulation often remains inaccessible, eclipsed in its turn in shadow, where it moves about and puts one off the trail. ${ }^{9}$

In effect, 'the conjuring trick' is language. To name a debate creates a debate, and breeds the haunted ontology of its subjects. Those who feel represented are reaffirmed as real, while those who are ignored or silenced perpetuate a ghost story and are removed from the debate. When the national public sphere, as represented by the Canadian Charter of Rights and Freedom and Bill C-16, provokes such a change, divisive debates spring up within its public. Public intellectual Jordan Peterson ${ }^{10}$ and Canadian politician Don Plett ${ }^{11}$ are examples of those who have criticized the amendment, and while neither amendment will be changed anytime soon, everyone in Canada (whether they agree or disagree with these rulings) begins to feel haunted. It is no longer a personal feeling as if 'time is out of joint'; 12 it is perpetual, never-ending and all-encompassing. Everyone feels the ghost in this story, which means that no one, and everyone, is in disagreement. It is those who are in the minority, however, who bear a more complicated legacy in the field of hauntology.

In Avery Gordon's Ghostly Matters: Haunting and Sociological Imagination, she examines 'how paying attention to ghosts can, among other things, radically change how we know and what we know about state terror and about slavery and the legacy of American freedom that derives from it'. ${ }^{13}$ One of the many ways she does this is through an examination of Toni Morrison's Beloved, a ghost story about slavery, which is Morrison's attempt to give voice to the 'sixty million and more' who were lost before the slave trade even began. ${ }^{14}$ It is to these lost bodies - those who effectively died during travel, in a liminal state of being not free but not yet a slave - that Morrison dedicates her novel, and it is these bodies which represent the cogent out-of-place-ness that a ghost story represents. To research the ghost story is to also make oneself out-of-place, since '[f]ollowing the ghosts is about making a contact that changes you and refashions the social relations in which you are located' and it also queers a person's sense of time, since they now 'strive to understand the conditions under which a memory was produced in the first place, [then] 
toward a countermemory, for the future'. ${ }^{15}$ In this way, the ghost story is phenomenological, spiritual, psychological, fictive, and, as Morrison echoes, is a story bound up in trauma, especially that of an entire people that occurred under slavery. Though Gordon is careful to caution that, ' $[\mathrm{h}]$ aunting is not the same as being exploited, traumatized, or oppressed', there is a definitive correlation in Morrison's Beloved where Beloved's presence in the text and her initial death - her time being made out of joint certainly 'involve[d] these experiences [of being oppressed] or is produced by them'. ${ }^{16}$ Furthermore, as Morrison develops in Playing in the Dark: Whiteness and Literary Imagination, the ghost of slavery as an institution continues to affect the United States through its constant national definition in the concept of freedom, since freedom can only exist with the notion of slavery lurking in the background. ${ }^{17}$ Gordon and Morrison both connect the idea of haunting to prohibition, especially the prohibiting of a speech-act or story, and especially if institutions, such as the US government, continue to perpetuate this silencing. By not talking about the past, the past does not cease to exist, but is repressed and made latent forced 'into the shadows'. ${ }^{18}$ 'To write stories concerning exclusions and invisibilities is to write ghost stories' Gordon says, and 'to write ghost stories implies that ghosts are real, that is to say, that they produce material effects'. ${ }^{19}$

In the context of our essay, we wish to examine the 'material effects' left by ghosts as words, be they hate speech, identity labels, or pronouns with complicated histories. ${ }^{20}$ For Tony Burgess's novel Pontypool Changes Everything and Bruce McDonald film adaptation Pontypool, the haunted legacies of certain words are transformed into contagious word viruses, which spread throughout a small town in Ontario called Pontypool and to the rest of Canada. It is this change from haunting to contagion which we argue is brought about through new media technology and the dispersion of communities through these technologies. Whether it is an isolated radio room in Pontypool where the three main characters are trapped, or the news media misrepresenting the public's outcry to the 1938 War of the Worlds' broadcast, or through online communities which Jordan Peterson ${ }^{21}$ and his online followers subscribe to, words continue to leave material effects which our article attempts to trace and analyze. By using some words and not others, or by forgetting the legacy associated with certain terms, a haunting persists and changes the way in which a country is shaped, along with the families and communities in that country. Moreover, to even say that the debate surrounding Bill C-16 or the national anthem is simply about pronouns is to misrepresent or misinterpret the complicated legacy of queer hauntings, since the only 
pronouns in question are pronouns for bodies that may seem as if they are mismatched - i.e. transgender or gender-nonconforming bodies.

In An Archive of Feeling: Trauma, Sexuality, and Lesbian Publics, Ann Cvetkovich describes what she calls 'low-level "insidious"' traumas which target the "everyday sexual lives in which the vulnerability of bodies and psyches is negotiated' in particular. ${ }^{22}$ In a way, these are smaller ghosts that are barely seen but always felt, and when compared to public and national trauma, can often be pushed aside; they are thought of as a nuisance, rather than a serious issue, which is precisely what happens to the debate surrounding gender neutral pronouns. To not be read as their gender identity, and then to have their request for that identity rejected through the use of the unrequested pronoun, means that transgender or gender nonconforming students experience 'the everyday life of queer trauma' as Cvetkovich presents it. ${ }^{23}$ Their daily lives, names and identities become haunted through repeated and sustained negative interactions, something of which is represented in the community itself through their use of the 'dead name' (sometimes stylized as deadname) as a term..$^{24}$ The dead name is the birth name of the trans person; when used after transition (be it social or medical or otherwise) has occurred, it is called being 'deadnamed', 'deadnaming', or simply being called by a 'dead name'. ${ }^{25}$ This term best encapsulates the traumatic feeling of being misgendered by a largely cisgender public sphere, according to the trans community, but it also conjures a ghost in the same way that being forcefully misread also does. To conjure this ghost from the past has serious consequences for the everyday existence of the trans person, both theoretically and practically. It can be dangerous for a trans person to be deadnamed since they may not be completely out to those who may hear the former name, and this conjuring could lead to consequences such as violence and/or loss of employment. Theoretically, however, using the term 'dead name' within the community replicates the cisgender public sphere's initial trauma; it sustains the haunting, rather than working towards healing it. Similar to Peterson's refusal to use gender neutral pronouns, calling a person by their dead name conjures a ghost, but so does calling it a dead name. These words perpetuate the same discourse; they are all 'conjuring trick[s]'. ${ }^{26}$ These words do also not allow the past to become integrated. Instead of the birth name being viewed as a relic, a part of the self that once used to exist but how now changed, the past has been erased and is prohibited from speaking.

These speech-act prohibitions do not alleviate the burden of transphobia, much like Gordon and Morrison note of other prohibitions that do not alleviate the legacy of racism and slavery, so Canada, and especially 
the trans people inside of its borders, continue to feel haunted, even in light of these recent changes to the national anthem and Bill C-16. The genderqueer students in Jordan Peterson's classes, for instance, along with trans people who are detained at Canadian borders ${ }^{27}$ or who were issued duplicate voting cards in Canada's 2018 election ${ }^{28}$ still regularly deal with the everyday life of queer trauma often conjured through their dead names or misuse of pronouns. In the age of new media, these community fractures and hauntings only continue to grow.

\section{Word Viruses}

The material effects of words shift from a haunting to a contagion through a mixture of technology and prohibition. Prohibited speech in the name of social cohesion - such as the gender-neutral lyrics for O Canada or Bill C-16 - creates a quarantined space where a lack has defined its borders. By claiming that there is no more 'free speech'29 for someone like himself due to these new amendments, Peterson (and others who may agree with him) perpetuates the idea of speech slavery, a rhetoric which derives its power from the same haunted ontologies that rob transgender and gender nonconforming people of their rights. As this fracture grows, these prohibited words - and the ideological messages attached to them spread as if they were viruses, effectively turning a haunting into a contagious culture. A 'word virus', then, is how ideology itself is made manifest through certain words and/or phrases, which can then be transferred through the use of a technological advancement to groups of people sometimes entire communities - which then fuses them together with a sustained belief system they continue to practice through the use of the phrases themselves. Canadian author Tony Burgess's transmission of a zombie virus spread through words (rather than through bodily contact) in Pontypool and its novel Pontypool Changes Everything is the best example of the word virus in action. While the novel version contains many different protagonists and a far bleaker outlook on how the word virus is spread, the filmic adaptation best represents the fear of an ideologically coded language virus and how this virus can be combated through new meaning-making practices in integrated, diverse communities. In Pontypool, DJ Grant Mazzy (Stephen McHattie) and his two coworkers, LaurelAnn (Georgia Reilly) and Sydney (Lisa Houle), receive messages about an incoming zombie invasion from their traffic-copter reporter, Ken, along with a garbled message broadcasted from a French station, and even from the BBC, but they do not believe it is real. Eventually, Laurel-Ann is infected 
and dies from the illness, while Grant and Sydney survive after taking Dr Mendez, a doctor who specializes in the virus, into the studio. It is through Dr Mendez, a stranger-outsider, who realizes the virus is a word virus, and not spread through typical means of contamination. His discovery shifts the tone of the movie from an everyday Southern Ontario Gothic tale of a small town turned ravenous swarm into an intelligent exploration on the ways in which we can use - and abuse - language.

Pontypool's plot closely mirrors - and subsequently inverts - the apocryphal 1938 case of the War of the Worlds broadcast. In the novel, H.G. Wells tells a rather straightforward story of a Mars invasion; the storyline was then adapted and presented for a modern American audience in the form of news bulletins. ${ }^{30}$ It was this format - as news, rather than as a radio play - which confused the population the most, but the numbers of people who were confused or panicked is vastly overestimated. ${ }^{31} \mathrm{It}$ was the newspaper industry, rather than the population, which created then propagated - the mass hysteria narrative; the news created and then spread a word virus. By creating an invasive narrative about an invasion, the aliens became an easy metaphor for whatever 'stranger danger' could be felt in the social milieu. ${ }^{32}$ Indeed, many subsequent horror films that dealt with contagion or invasion were thinly veiled metaphors for spreading malicious ideas, be they racial inequality (Night of the Living Dead), ${ }^{33}$ communism (Invasion of the Body Snatchers) ${ }^{34}$ or technological progress (The Thing). ${ }^{35}$ Zombies in particular have become synonymous with invasion metaphors, since the zombie represents 'a recognizably human (if not familiar) figure that devours the living'. ${ }^{36}$ Furthermore, when zombies swarm, these narratives 'display an explicit fear of a foreign invasion', especially in relation to racial politics in the United States. ${ }^{37}$ The zombie as a metaphor represents the tension between who is insider/ outsider in a particular community, and the zombie as a horde, swarm, or pack represent the mounting fear of ideological take over especially as time moves on.

In Pontypool Changes Everything and Pontypool, the figure of the zombie is used to make a direct connection to ideology as infectious, but instead of using the bite or wound to spread the infection, a word or phrase bears the weight of transmission. In the novel and movie, the outbreak is spread through certain words and phrases (not always the same from person to person), which then causes aphasia in the victim, and subsequent death and destruction. Those who perish are usually devoured by others; the zombies are interchangeably called zombies or cannibals in the novel and film. One of the more fascinating parallels in the novel between the zombie-cannibal figure is the evocation of the real life serial killer Ed 
Gein ${ }^{38}$ who 'redecorated his farmhouse with body parts'. ${ }^{39}$ When Les, one of the several oscillating main characters of the novel, discovers that the local high school wants to do a play about Ed Gein (rather than his more traditional favourites), he refers to the 'cannibal thing' as just another problem he has to deal with during the day. ${ }^{40}$ Later on, when Les is in a police station, the narrator describes him as being unaware of 'a growing number of people in Ontario [who] are now also giving the opp murder' along with 'vicious gangs of cannibals [who] are moving on the police, sweeping through like a system of weather, snatching up large parts of the population'. ${ }^{41}$ While this last quotation clearly displays the connection to Pontypool's predecessors in the zombie genre, the conflation of the cannibal to the zombie is fascinating in terms of what it means for consumption. Rather than consuming flesh, the cannibals and zombies in Burgess's world are Ed-Gein-like figures who merely 'redecorate' 42 with body parts; they collect and redistribute, rather than consume and infect. Indeed, the gore associated with Ed Gein - one of the main sources of the slasher archetype in cinema ${ }^{43}$ - is reduced to a shticky high school play; a 'dramaturgical inevitability as a home-shopping network sketch', thereby rendering all bodies and gore associated with them jokes. ${ }^{44}$ Instead it is Burgess's treatment and description of the 'word virus' as the true source of contagion in his text that is truly terrifying to the members of Pontypool and makes both the novel and film stand out amongst the horror genre filled with gore and destruction. In the novel, Burgess describes the word virus as having

hid silently for decades up in the roofs of adjectives, its little paws growing sensitive, first to the modifications performed there; then, sensing something more concrete pulling at a distance, the virus jumped into paradigms. It was unable to reach the interior workings of the paradigm, however, due to its own disappearance near the core. The viruses bit wildly at the exterior shimmer of the paradigms, jamming selection with pointed double fangs. A terrible squealing ripped beneath the surface of the paradigms as they were destroyed. The shattered structure automatically redistributed its contents along syntagma, smuggling vertical mobiles across horizontal ropes. What was in the air had to travel as ground and the virus sauntered right into these new spaces, taking them over. Radical spaces evolved to compensate. Negative space became a fortune telling device. Positive space arched its back painfully, now pocked horribly by the frenzied migration of vehicles into the ground. ${ }^{45}$ 
His description is deliberate and invokes precisely that combination of ideology, prohibition and transmission to groups. In this description, words are the virus, but they are also the technological vehicle which are used to spread the ideological message, 'the exterior shimmer of the paradigms'. ${ }^{46}$ This is significant since new media technologies - such as the radio station itself - may help facilitate transmission/infection to a broader population, but these technologies can be shut off or ignored without actually eradicating the true source of infection. The solution to the spread of the ideology virus, then, is to break apart the words that bear the full weight of transmission and change their meanings, something which Grant figures out in the final act of the movie. Because of this, we use the film adaptation as a speculative case study in which to examine how the film represents - and then inverts - the typical construction of the insider/outsider, but also for this innovative solution the film presents. Rather than prohibiting speech through quarantine, the main characters realize that they must change the meanings of the words themselves - which means questioning and changing the ideology that binds them.

\section{Pontypool as Case Study}

From the very beginning of the film, the audience defines the town Pontypool through sound. The adaptation process from the novel to the film has made the aural focus of the virus transmission process that much more obvious and sonic. Burgess's description of the virus 'in the air' now has to 'travel . . . right into these new spaces, taking them over' and these new spaces of the cinema screen must be dominated by auditory chatter in order to construct Pontypool from 'negative space'. ${ }^{47}$ The opening title sequence is a pre-tape Grant Mazzy has done about Mrs French's missing cat, which is played over a screen that gradually spells Pontypool out of sequence. The jumbled letters jumble the meaning of the word itself - the first comprehensible word we are given is TYPO - and this disorientation is furthered through Grant's endless chatter over the mic, along with the visual equivalent of what his voice sounds like. The first scene after the title sequence is Grant driving and being accosted by a woman he does not know and who will not answer him (later on, she becomes a zombie in a horde). When Grant shows up at the radio station, he encounters his own pre-taped voice outside. When finally on the air himself in real-time, he continues his own endless monologue, sometimes enticing both Sydney and Laurel-Ann to also contribute to the conversation - until, of 
course, the zombie outbreak becomes audible and Sydney refuses to have it on the air.

The tension between silence/prohibition and excessive information/ chatter is also made quite clear through the opposing figures of Grant and Sydney. While Grant represents endless chatter in the name of 'full disclosure', Sydney appeals to prohibition in the name of 'professionalism' and peace-keeping. When reports of the zombie invasion become frequent and alarming, Sydney insists that they should not worry the members of the small community unnecessarily with news reports which may not be real; instead she fills the dead-time with weather updates, traffic, school closures, and a previously scheduled performance of Lawrence of Arabia. Pontypool has been made through sound, but only what is permitted to become sound. As Sydney remarks, Pontypool is filled with gossip: Mrs French's cat is one of many stories which are reiterated in order to construct a sonic image of Pontypool, since the filmic audience will never actually witness the town itself. When the three workers are informed they are under quarantine, Pontypool as a town and as a movie becomes confined to the radio room itself, and each one becomes a representative member of the community.

It is after the quarantine when the notion of the 'outsider' first appears as a solid concept - or at least, a cogent voice on the phone. Though the three leads hear about the invasion of the medical hospital where Dr Mendez works, and where the first swarm was spotted over the phone, Sydney refuses to play it in its entirety. Similarly, the French message they receive over the air is translated and broadcasted, but then ignored. The BBC newscaster's report on the invasion manages to get on the air, but it is discredited when they bring up 'separatist terror groups'. Sydney writes the report off as an outside country not understanding Canadian politics. ${ }^{48}$ Furthermore, the only townsperson from Pontypool giving the radio station information is Ken from his 'traffic copter'. He is discredited when Sydney reveals that Ken is not actually in a helicopter, but in his car and playing sound effects; later on his credibility is eroded even further when Sydney reveals that he was actually a pedophile. This reveal is made after he has died over the phone, and after Laurel-Ann has become infected with the word virus. Though they know that the invasion is real at this point, Sydney continues to distance herself from the validity of the experiences they are having through discrediting of Ken. From the very beginning of Pontypool, it is the outside world's interpretation of the emergency happening in Pontypool that's doubted, rather than the radio broadcaster's creation of an invasion that scares the townspeople. 
When Dr Mendez climbs in through the window into the radio station, he becomes the perfect symbolic visualization of the outsider/invader and a beacon of 'stranger danger' during this crisis. ${ }^{49}$ Mendez is also the only non-white character we have in the film, though his racial identity remains ambiguous in the source text. Dr Mendez is one of the few characters who appears in both the book and the film, but the novel does not give him much physical description. The only insights into Mendez's personality come from Les's internal monologue ('He's a bit loony, isn't he?') ${ }^{50}$ and from one scene when Dr. Mendez performs 'loose little dances' around the bodies of cadavers so he can distinguish himself as 'not being dead' in the zombie carnage. ${ }^{51}$ These small descriptions, in addition to his nonwhite (or racially ambiguous) surname, code him as a character out of place in the small town setting of Pontypool, something on which the film builds when it depicts him as breaking into the radio station. Since it was also Mendez's clinic which was the focal point for the invasion, he becomes the centre of the swarm and the embodiment of the virus - at least on the surface. While Mendez acts as the alien-outsider, he brings knowledge of the virus. Indeed, it is his status as a body out of place - as the only living survivor in a wreckage of zombie death - which gives him the experience to figure out how the virus is transmitted and spread. The 'stranger danger' of the alien outsider lessens - not because his body or racial ambiguity has been resolved necessarily, but because his 'passport' and credentials have passed the test. ${ }^{52}$

It is at this point in the narrative when we realize that the English language - and whiteness - is symbolic of the invasion. As the woman who first refused to speak to Grant in his car is found in a zombie horde, and as Laurel-Ann's communication breaks down with the virus, the audience's notion of the stranger is summarily revised: the stranger is not those who are bodily different, but those who refused to connect. The stranger also becomes sutured to the State/government itself through Laurel-Ann's depiction, since she was once a soldier overseas and has recently returned. It is also the State/government who places the town under quarantine, and who later destroys the radio station under the guise of protecting the community. The inversion of the alien-outsider is furthered when Grant and Sydney realize a zombie has gotten inside the radio studio and are forced to kill it; the zombie is a child from a previous performance in the radio booth earlier that day of Lawrence of Arabia, and the child has been in brown-face for the performance (along with the two adults $^{53}$ and other children). The brown-face performance goes uncriticized by the characters in the film, though Grant is highly uncomfortable with their presence in the studio. Since the performance interrupts 
the time he could have spent on-air talking about the virus, however, Grant's discomfort could either be a need to speak again, or apprehension about the bad praxis of brown-face. Either way, we view the brown-face performance as a deliberate way to counter and challenge the audience's assumption about the insider/outsider, similar to the introduction of Dr Mendez's character. The audience is primed to see Mendez as a 'body out of place' and as Sara Ahmed notes, these bodies out of place often become conflated with the 'could be terrorist' due to their inability to be integrated into the community. ${ }^{54}$ This is not the minority's fault, but rather gestures to these larger ideologies of racism, sexism and nationalism which label certain bodies as belonging and others as not. Mendez's racial identity remains ambiguous in the film, though he is eventually integrated into the community, while the children and adults' brown-face identity remains clearly a (rather off-putting) mask and one that ends up becoming deadly when the child turns zombie. During the performance, the child that later attacks Grant and Sydney showed signs of aphasia by uttering 'par par par'; just before it attacks them, it mimics and repeats what Sydney has just said, thus marking it as infected. The Lawrence of Arabia performance then becomes representative of the small-town ethos: whiteness that pretends to be strange and exotic as a way to entertain and feign inclusivity, but they only become infected with these haunted legacies of colonialism, imperialism and racism, and then tries to pass them onto others through new media technology, such as the brown-face radio play.

As Jasbir Puar notes, building on the work of José Esteban Muñoz, there is a narrative of the 'double-agent' or 'terrorist drag' that occurs when gender markers on documentation, such as the passport, do not match the body. ${ }^{55}$ The transgender or gender non-conforming body is one that is intensely 'out of place' - especially in a small town. ${ }^{56}$ Since small towns, or the 'south' in the horror canon, are typically seen as a place of regression, atavism and 'patriarchy run amok', queerness is often punished or demonized. ${ }^{57}$ Leatherface from Texas Chainsaw Massacre or the inbred desire of The Hills Have Eyes are quintessential examples; the first example of Leatherface also draws its inspiration from the real life source of serial killer Ed Gein. ${ }^{58}$ As stated earlier, Gein is evoked as the "cannibal thing' that is part of the small town life Les (and others) must now deal with, even when it's merely a high school play. ${ }^{59}$ In the horror genre, the small town is especially dangerous for the way in which it twists nonnormative forms of embodiment into monstrosity, and in the smaller subgenre of literary horror known as Southern Ontario Gothic, the small town becomes the source of 'cabin fever' for its protagonists. ${ }^{60}$ The cabin fever for which Southern Ontario Gothic writers (such as Timothy 
Findley, Margaret Atwood, and Alice Munro) are known deliberately hinges the horror on the lack of communication; it is 'uncommunicative husbands' or an inability to understand the depths of the wildness which causes 'strange projections and psychological grotesqueries [to] spring up and rapidly grow to unmanageable proportions'. ${ }^{61}$ With Tony Burgess's novel and film, the small town is depicted as regressive due to its bad ideology (as made manifest in brown-face), but it does not focus on the body as the point of infection. Instead infection happens through the ways in which language can be used, understood or misunderstood.

Laurel-Ann's infection, among all others, demonstrates the connection between the normative body, invasive ideology, and community bonds the best. Her affliction is invisible until she speaks, and when she does, she is unable to be understood as she breaks down into aphasia. She then follows her non-afflicted coworkers to a sound-proof recording studio where they seek quarantine. While they are safe, she is unable to be heard, recognized or validated. When she is unable to pass on the language virus, she dies vomiting a stream of blood onto the glass in an almost desperate outpouring of inner bodily turmoil. As the film continues, Laurel-Ann's outsider status is further exacerbated as we receive several shots of her twisted, gory mouth - this is the place where bad ideology could not be spread, but desperately wants a community. Pontypool also makes a claim that while the zombie horde is definitely a community (one which Laurel-Ann could not join since she did not pass on the virus), it is one that is as sick in the words they use. One of the first messages the radio station receives about the invasion is in French. The translation (by Laurel-Ann), is as follows:

For your safety, please avoid contact with close family members and restrain from the following: all terms of endearment such as honey or sweetheart, baby-talk with young children, and rhetorical discourse. For greater safety, please avoid the English language. Please do not translate this message.

The message implies that those with whom we are intimate are those most easily infected, since we share discourse communities and common understandings with them. Instead of fearing the stranger, then, Pontypool suggests we should learn to revere the stranger since they will force us out of own discourse communities, ideologies and perhaps our prejudices. This point is furthered through the contrast of Mendez's character, the small child, Laurel-Ann, Ken in his traffic copter and the woman from the beginning. We are prone to see Mendez as the stranger right away, but 
then he is redeemed precisely because of his strange status and his credentials. In contrast, the others are perceived to be familiar or at least belonging in Pontypool, but they are the ones who are actually violent: the woman hits Grant's car, Ken is a pedophile, Laurel-Ann vomits blood and the child wounds Sydney. It is here - when Sydney becomes infected because of the word 'kill' and not the child's bite - that Pontypool changes the standard zombie trope of invasion and makes it into a haunting.

The horror of the movie - voices over the phone, the horde/herd, the warnings - all come through sound, rather than gore. In this way, Pontypool positions itself as both a zombie and ghost story. Indeed, it is the sound of the zombies makes them into literal poltergeists, as the term poltergeist is from two German words roughly translating into 'noisy spirit'. That 'noise' which disrupts their spirits is precisely ideology, the sticky paradigms and parasitic speech patterns of Tony Burgess's novel adapted to the screen. Even as Laurel-Ann becomes infected and the zombie horde emerges, so much of the horror is conveyed aurally rather than visually. The audience becomes aware that she is infected through her mangling of sentences and alliteration, which marks the beginning of aphasia and the first symptom of the illness. After repeating several iterations of 'Mr. Mazzy's missing' she then mimics a tea kettle, like someone earlier in the film mimicked windshield wipers. When all words fail her, she bangs and taps on the glass trying to be let inside the soundproof booth. Even as Laurel-Ann begins to bleed from her mouth, the horror of her transformation is in the sonic quality of her banging and the sound of her retching. The other zombies are similar: it is their sound, not their bodies, which scare the viewers and those trapped inside the radio station. Much of this has to do with the restraint of the filmic scene itself, since almost the entire film is shot in the radio studio. The film's focus of sound is also what turns the mere words into a vehicle for viral transmission. Sound is part of the technology of the word virus, since words written down do not have the same power of infection; words must be spoken in order for the virus to pass on.

Sydney's infected word ends up being 'kill', precisely because she has forced many people into silence; she has 'killed' many of Grant's stories before they could be uttered, in effect, killing all sound before it could go on the air. As the film escalates, and especially as Dr Mendez also becomes infected and they cannot maintain a conversation outside of English, Sydney changes her mind about who is outsider/insider, what intimacy means and what speech acts are allowed - as has Grant. Grant once used to espouse 'full disclosure', but his forced silence for the sake of social order leads him - not to a gory ruin like Laurel-Ann or a zombie horde full of 
mindless chatter - but towards a solution, a way to 'disinfect' language. In Grant's case, to 'disinfect' the word means to change the ideology behind it, and if 'kill' is what infected Sydney, then Grant must find a way out of this repetitive discourse loop. He goes through a variety of alternative meanings for 'kill' but 'kill is kiss' is the only one that resonates. He turns to Sydney, his counterpoint for most of the film, and closes all distance between them by chanting 'kill is kiss' until they really do embrace. All forms of strangeness are removed in this act; there is no outsider; and for a moment, there is no language.

This cure works. By changing the meaning of the word, Grant enables Sydney to reverse the infection, but it also changes the relationship between the two of them. Instead of remaining on opposing sides, or declaring one of them as correct, they simple change the meaning of the debate and the situation they have been forced into. They broadcast their cure to the rest of the province, though their transmission is eventually stopped by commands from a French officer. They are told to cease what they are doing, since the military believes it is spreading the infection. Grant accuses the disembodied voice shouting commands of 'always killing scared people' and then declares that 'we were never making sense'. His Network-esque monologue echoes his discovery, while also making it mundane; this was just an average day in Pontypool, where bad ideologies run wild, but where maybe, instead of killing the enemy-outsider, we kiss them instead. While the French military counts down to the final act of quarantine and silencing of Grant and Sydney, however, the audience gets one last kiss between them.

We are, in theory, not supposed to know what happens, though it is heavily implied Grant and Sydney do not live. However, kill does not mean kill anymore, so perhaps - like the end credit sequence of the film implies - Sydney and Grant have run away and fallen in love instead. Either way, Sydney's infection and eventual cure through Grant's gestures represents our final position in this paper, which is that prohibition does not work, nor does constant information (such as we get in the age of new media). Instead we must focus on the words themselves and what messages they carry 'silently for decades up in the roofs of adjectives' in order to remove a legacy of haunted history from our communities. ${ }^{62}$

\section{Conclusion}

Near the end of Pontypool, the national anthem comes over the loudspeaker. It is a sudden and stark interruption; one that draws the zombies 
towards Grant and Sydney, and renders them vulnerable to danger. To stop the imminent attack, they take a hammer to the loudspeaker; they fight the noise, rather than the horde. In this way, the national legacy of Canada has let them down, rather than the population inside the country's borders, even if they are equally infected and afflicted. The scene reminds us of the changing words in the anthem in 2018. While it looks like progress, to some it looks like prohibition, and to others, both look like the same thing. In order to make the places in which we live habitable, Tony Burgess's Pontypool Changes Everything, and especially its film adaptation Pontypool, suggests we cannot ignore the country's previous haunting, or even the stranger-outsiders who seem afflicted. Instead we must live with the ghosts, zombies and strangers, and learn to speak to them in a language we both understand, in order to bring better ideas alongside the bad.

\section{Notes}

1 John Paul Tasker, 'Senate passes bill to make O Canada lyrics gender neutral', CBC News. 31 January 2018, http://www .cbc.ca/news/politics/anthem-bill-passes -senate-1.4513317.

2 Casey Plett, 'For transgender Canadians, Bill C-16 is symbolic-yet meaningful', Macleans, 19 June 2017, https://www .macleans.ca/opinion/for-transgender -canadians-bill-c-16-is-symbolic-yet -meaningful/.

3 Sara Ahmed, Queer Phenomenology: Orientations, Objects, and Others, (NY: Duke University Press, 2006), 141.

4 Jacques Derrida, Specters of Marx, (New York: Routledge, 2006), E-Pub, 30.

5 Pontypool (Bruce McDonald, 2008).

6 Tony Burgess, Pontypool Changes Everything, (Toronto: ECW Press, 1998).

7 Ahmed, Queer, 141.

8 Derrida, Specters, 30.

9 Derrida, Specters, 156.

10 Lisa Cumming, 'Are Jordan Peterson's Claims about Bill C-16 Correct?', The Torontoist, 19 December 2016 https:// torontoist.com/2016/12/are-jordan -petersons-claims-about-bill-c-16-correct.

11 Casey, 'For transgender Canadians'.

12 Shakespeare qtd. in Derrida, Specters, 18.

13 Avery Gordon, Ghostly Matters: Haunting and Sociological Imagination (Minneapolis: University of Minnesota Press, 2008), 17.
14 Toni Morrison, Beloved (New York: Vintage), 1987, 1.

15 Gordon, Ghostly, 22.

16 Gordon, Ghostly, xvi.

17 Toni Morrison, Playing in the Dark: Whiteness and Literary Imagination (Cambridge, MA: Harvard University Press, 1992), 20-27.

18 Gordon, Ghostly, 17.

19 Gordon, Ghostly, 17.

20 Gordon, Ghostly, 17.

21 Cumming, 'Are Jordan Peterson's Claims?'.

22 Ann Cvetkovich, An Archive of Feelings: Trauma, Sexuality and Lesbian Publics (London: Duke University Press, 2003), 29.

23 Cvetkovich, Archive, 15.

24 Sam Reidel, 'Deadnaming a Trans Person Is Violence-So Why Does the Media Do It Anyway?', The Establishment, 6 March 2017, https://theestablishment.co /deadnaming-a-trans-person-is-violence -so-why-does-the-media-do-it-anyway -19500eda4b4.

25 Reidel, 'Deadnaming a Trans Person'.

26 Derrida, Specters, 156.

27 Lisa Scott, 'Gigi Gorgeous Allegedly Detained in Dubai for being Transgeder', Global News, 10 August 2016, https:// globalnews.ca/news/2875688/gigi -gorgeous-allegedly-detained-in-dubai-for -being-transgender/. 
28 Julien Gignac, “It's super infuriating”: Trans voters react to receiving registration cards with their former names', The Toronto Star, 4 June 2018, https://www .thestar.com/news/gta/2018/06/04/its -super-infuriating-trans-voters-react-to -receiving-registration-cards-with-their -former-names.html.

29 Cumming, 'Are Jordan Peterson's Claims?'

30 H. G. Wells, War of the Worlds (Mineola: Dover Publications, 1998).

31 Jefferson Pooley and Michael J. Socolow, 'The Myth of the War of the World's Panic', Slate.com, 28 October 2013, http://www.slate.com/articles/arts /history/2013/10/orson_welles_war_of _the_worlds_panic_myth_the_infamous _radio_broadcast_did.html.

32 Ahmed, Queer, 142.

33 Night of the Living Dead (George A. Romero, 1968).

34 Invasion of the Body Snatchers (Philip Kaufman, 1978).

35 The Thing (John Carpenter, 1982).

36 Mikel J. Koven, Films, Folklore, and Urban Legends (Maryland: Scarecrow Press, Inc., 2008), 39.

37 Koven, Films, 92.

38 Ed Gein was a Wisconsin serial killer from the 1950s who murdered two women, but was more known for his grave robbing and farmhouse filled with items made from corpses. He is the basis for many slasher serial killers, such as Norman Bates, Buffalo Bill, and Leatherface. See K.E. Sullivan for more. K. E. Sullivan, 'Ed Gein and the figure of the transgendered serial killer', Jump Cut: A Review of Contemporary Media, (No. 43, July 2000).

39 Burgess, Pontypool, 19.

40 Burgess, Pontypool, 19.

41 Burgess, Pontypool, 101.

42 Burgess, Pontypool, 19.

43 Sullivan, K.E, 'Ed Gein'.

44 Burgess, Pontypool, 19.

45 Burgess, Pontypool, 147-148.

46 Burgess, Pontypool, 147.

47 Burgess, Pontypool, 148.

48 Sydney's reference to the BBC's assumption of a separatist terrorist group is one way in which Pontypool works towards a unified version of Canada, where Quebec's separatist past is ameliorated (or outright forgotten, depending on perspective). We see the film as positive to Quebec's past. The French language is represented as a way in which the population can beat the language virus, at least temporarily. Even when the French officers obliterate Pontypool at the end of the film, there is no assumption that these officers are Quebec separatists: officers are speaking French because it is a viable solution to the English word virus transmission, and because it is one of Canada's official languages. A more thorough reading could be done juxtaposing the image of the terrorist in the film (US vs. Canadian perspectives perhaps), but for the most part, the 'could be terrorist' as Ahmed views it is not a French separatist in this film, though outsiders - like the BBC - try to interpret it this way.

49 Ahmed, Queer, 140-142.

50 Burgess, Pontypool, 78.

51 Burgess, Pontypool, 131.

52 Ahmed, Queer, 140-142.

53 It is important to note that the author, Tony Burgess, is one of the adults in brown-face. Since he also wrote the screenplay, we argue that his presence here - of all places - in the film is meant to act as a way we are to deconstruct his authority as author of the novel. This is partly why we focus so much on the film, rather than the novel version of the storyline, since we read Burgess's implied deconstruction of his authority as him revising his initial text.

54 Ahmed, Queer, 140-142.

55 Jasbir Puar, Terrorist Assemblages: Homonationalism in Queer Times, (Durham, NC: Duke University Press, 2009), xxiii.

56 Ahmed, Queer, 141.

57 Clover, Carol, J., Men, Women and Chainsaws: Gender In Modern Horror Films, (NY: Princeton University Press, 1992), 125.

58 Sullivan, 'Ed Gein', 38.

59 Burgess, Pontypool, 19.

60 William Toye and Eugene Benson, 'Southern Ontario Gothic', in The Oxford Companion to Canadian Literature (2 ed.), (Oxford University Press, 2006), n.p., Digital.

61 Toye and Benson, Oxford Companion, n.p.

62 Burgess, Pontypool, 147. 


\section{Bibliography}

Ahmed, Sara. Queer Phenomenology:

Orientations, Objects, and Others, (Durham, NC: Duke University Press, 2006).

Burgess, Tony. Pontypool Changes Everything, (Toronto: ECW Press, 1998).

Clover, Carol, J., Men, Women and Chainsaws: Gender In Modern Horror Films, (Princeton, NJ: Princeton University Press, 1992), 125.

Cumming, Lisa. 'Are Jordan Peterson's Claims about Bill C-16 Correct?', The Torontoist, 19 December 2016 https://torontoist .com/2016/12/are-jordan-petersons -claims-about-bill-c-16-correct.

Cvetkovich, Ann. An Archive of Feelings: Trauma, Sexuality and Lesbian Publics (Durham, NC: Duke University Press, 2003).

Derrida, Jacques. Specters of Marx, (New York: Routledge, 2006)

Gignac, Julien. “'It's super infuriating": Trans voters react to receiving registration cards with their former names', The Toronto Star, 4 June 2018, https:// www.thestar.com/news/gta/2018/06 /04/its-super-infuriating-trans-voters -react-to-receiving-registration-cards -with-their-former-names.html.

Gordon, Avery. Ghostly Matters: Haunting and Sociological Imagination (Minneapolis: University of Minnesota Press, 2008)

Koven, Mikel J. Films, Folklore, and Urban Legends (Lanham, MD: Scarecrow Press, Inc., 2008)

Morrison, Toni. Beloved (New York: Vintage, 1987).

Morrison, Toni. Playing in the Dark: Whiteness and Literary Imagination (Cambridge, MA: Harvard University Press, 1992).

Plett, Casey. 'For transgender Canadians, Bill C-16 is symbolic - yet meaningful', Macleans, 19 June 2017, https://www .macleans.ca/opinion/for-transgender -canadians-bill-c-16-is-symbolic-yet -meaningful.

Pooley, Jefferson and Michael J. Socolow. 'The Myth of the War of the World's Panic', Slate.com, 28 October 2013, http://www.slate.com/articles/arts /history/2013/10/orson_welles_war _of_the_worlds_panic_myth_the _infamous_radio_broadcast_did.html.

Puar, Jasbir. Terrorist Assemblages:

Homonationalism in Queer Times, (Durham, NC: Duke University Press, 2009).

Reidel, Sam. 'Deadnaming a Trans Person Is Violence-So Why Does the Media Do It Anyway?', The Establishment, 6 March 2017, https://theestablishment .co/deadnaming-a-trans-person-is -violence-so-why-does-the-media-do-it -anyway-19500eda4b4.

Scott, Lisa. 'Gigi Gorgeous Allegedly Detained in Dubai for being Transgender', Global News, 10 August 2016, https:// globalnews.ca/news/2875688/gigi -gorgeous-allegedly-detained-in-dubai -for-being-transgender.

Sullivan, K. E. 'Ed Gein and the figure of the transgendered serial killer', Jump Cut: A Review of Contemporary Media, (No. 43, July 2000).

Tasker, John Paul. 'Senate passes bill to make O Canada lyrics gender neutral', $C B C$ News. 31 January 2018, http://www .cbc.ca/news/politics/anthem-bill -passes-senate-1.4513317.

Toye, William and Eugene Benson, 'Southern Ontario Gothic', in The Oxford Companion to Canadian Literature (2 ed.), (Oxford: Oxford University Press, 2006).

Wells, H. G. War of the Worlds (Mineola, NY: Dover Publications, 1998).

\section{Note on Contributors}

Evelyn Deshane received an MA from Trent University and is currently completing a $\mathrm{PhD}$ at the University of Waterloo. Her creative and non-fiction work has appeared in Plenitude Magazine, Briarpatch Magazine, Strange Horizons, Lackington's, and Bitch Magazine, among other 
publications. Her most recent project \#Trans is an edited collection about transgender and non-binary identity online.

R. Travis Morton is a PhD candidate in English Literature at the University of Waterloo. His research areas include game studies, linguistics, political theory, American Literature, horror fiction, and folklore studies. He completed his MA at Trent University, where he wrote his thesis on narrative structures in video games on Bethesda Studios' Fallout 3. His dissertation involves independent survival horror games with a special focus on Slender: The Awakening and the proliferation of online folklore.

\section{Conflict of Interests}

The authors declare that there are no conflicts of interests with this work. 